\title{
PRE-ANGKORIAN SETTLEMENT TRENDS IN CAMBODIA'S MEKONG DELTA AND THE LOWER MEKONG ARCHAEOLOGICAL PROJECT
}

\author{
Miriam T. Stark \\ Department of Anthropology, University of Hawai'i-Manoa, Honolulu, Hawaii 96822, USA
}

\begin{abstract}
Polities in the Mekong delta played a central role in regional developments between $500 \mathrm{BC}$ and $A D 500$. Documentary data suggest the delta reached its political apex during the $3^{\text {rd }}$ through $7^{\text {th }}$ centuries. What were the roots of early polities in this region, and what was their organization? Research by the Lower Mekong Archaeological Project seeks to answer these questions through field investigations in southern Cambodia. Excavations at the ancient capital of Angkor Borei suggest a continuous occupation of the area from the $4^{\text {th }}$ century BC onwards; the timing, development and nature of interregional networks are now under study. This presentation describes some results of research at Angkor Borei, and discusses ongoing research on the communication and settlement systems that characterized the northern section of the Mekong delta from $500 \mathrm{BC}$ to $A D 500$.
\end{abstract}

The Mekong delta played a central role in the development of Cambodia's earliest complex polities from approximately $500 \mathrm{BC}$ to $\mathrm{AD} 600$. In what is now southern Cambodia and southern Vietnam (Fig. 1), substantial populations established new coastal and inland settlements, constructed religious monuments within their cities and in the surrounding countryside, and participated in the South China Sea economic and social network that linked cultures from China to Rome. Four southern provinces in Cambodia's Mekong delta (Prei Veng, Svay Rieng, Kandal, and Takeo) contain the delta's highest density of early historic sites, and most $7^{\text {th }}-8^{\text {th }}$ century inscriptions (Jacob 1979; Jacques 1979, 1995; Vickery 1998). A wealth of archaeological, epigraphic and art historical data suggests that this region's centrality continued throughout much of the subsequent preAngkorian period (c. AD 500-802).

The Lower Mekong Archaeological Project (hereafter "LOMAP") was established in 1996 to investigate models of early state formation in southern Cambodia. LOMAP Phase II began in 2003, and primarily involved a regional survey program in Takeo Province. The three-year survey was designed to locate and analyze the distribution of first millennium AD settlements associated with either the "Funan" or the Pre-Angkorian periods. Results of our survey work suggest that earlier historical models based on Chinese accounts of "Funan" underestimate the region's importance, and that it played critical political and social roles until at least the end of the pre-Angkorian period.

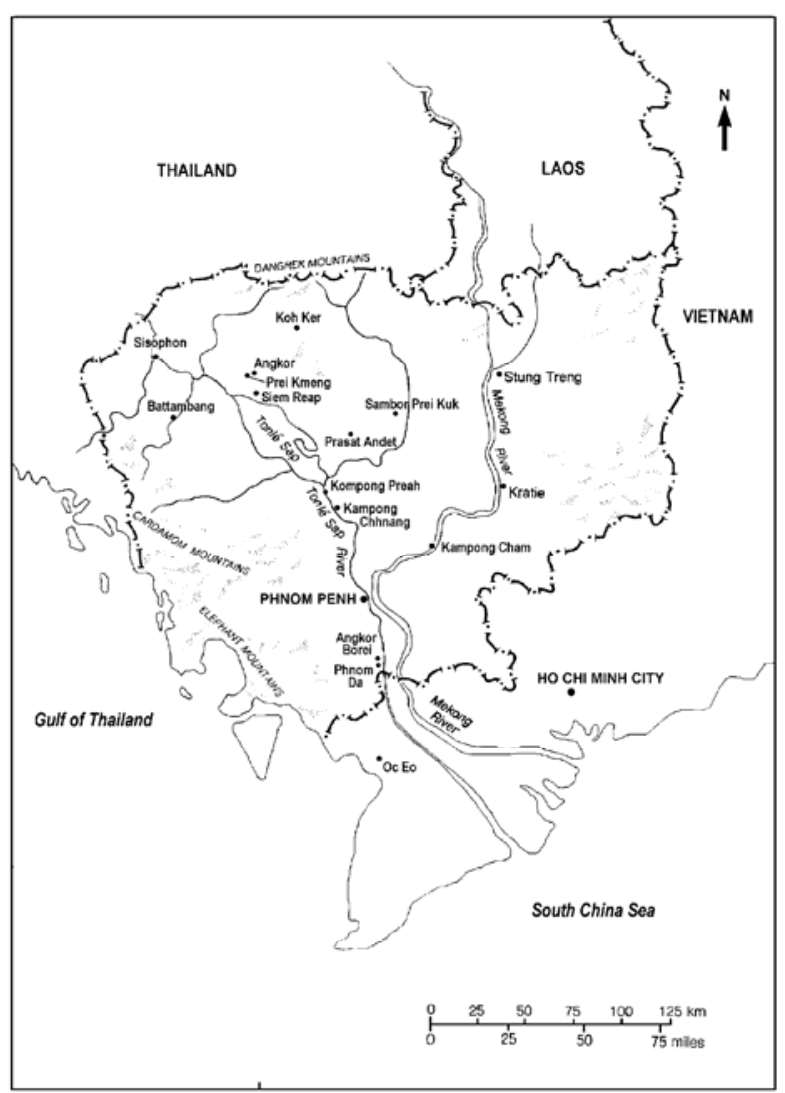

Figure 1. Location of Angkor Borei in Takeo Province (Cambodia). Reprinted with permission from the University of Hawaii Press from Figure 1, p. 52 in "A New Date for the Phnom Da Images and Its Implications for Early Cambodia." by N.H. Dowling, Asian Perspectives 38(1):51-61.

This paper draws from a decade's worth of archaeological investigations to discuss pre-Angkorian settlement trends in the LOMAP study area (e.g., Bishop et al. 2003a, 2003b; Bong 2003; Sanderson et al. 2003; Stark 1998, 2003a; Stark and Bong 2001; Stark et al. 1999; Voeun and von den Driesch 2004). This article has 
four sections. I first present a background to the Lower Mekong Archaeological Project, and discuss key research themes that structure LOMAP research. Findings from LOMAP excavations at and around Angkor Borei are then summarized, and preliminary findings from the LOMAP survey are discussed. This article concludes by expanding its focus beyond the Mekong delta to think more broadly about the Mekong basin.

\section{BACKGROUND TO LOMAP AND RESEARCH THEMES}

The Lower Mekong Archaeological Project is a direct outgrowth of the University of Hawaii/East-West Center/Royal University of Fine Arts Cambodia Project that was initiated in 1994 by Dr Judy Ledgerwood (then of the East-West Center) and Dr P. Bion Griffin (University of Hawai'i) and initially supported by the East-West Center. At the invitation of Cambodia's Ministry of Culture and Fine Arts, the larger Cambodia project was established to provide a foundation for longterm research and training programs by University of Hawai'i faculty that involve training graduates of the Royal University of Fine Arts (Phnom Penh) in archaeology, art history, cultural anthropology, and historic preservation (Griffin et al. 1996; Griffin et al. 1999).

The Lower Mekong Archaeological Project (hereafter called LOMAP) represents a product of this larger Cambodia Project. LOMAP was established in 1996 by co-directors Chuch Phoeurn (then Dean, Archaeology Faculty, Royal University of Fine Arts, Ministry of Culture and Fine Arts) and Miriam Stark (Department of Anthropology, University of Hawaii). LOMAP has concentrated most of its archaeological research on the archaeological site of Angkor Borei in Takeo province. Our fieldwork combines archaeological research and training and uses a variety of field techniques, from excavation and survey to geoarchaeological prospecting and coring. Several graduate students from the University of Hawaii (and other American and Australian universities) and more than 30 graduates from the Archaeology Faculty of the Royal University of Fine Arts have participated in LOMAP fieldwork since 1996.

\section{Research Themes}

Chinese documentary evidence sheds light on the earliest polities of the Mekong delta: envoys Kang Dai and Zhu Ying visited the delta in the mid- $3^{\text {rd }}$ century AD to explore the nature of the sea passage via Southeast Asia to India (Coedès 1968; Pelliot 1903). These Chinese dignitaries described customs of the peoples who lived in the "Kingdom of Funan", its multiple urban centers, political hierarchy, institutionalized religion, writing and economic specializations. Scholars who have examined Chinese documentary sources to understand Funan political developments (e.g., Coedès 1968; Hall 1982, 1985; Ishizawa 1996; Jacques 1979; Malleret 1959, 1960,1962; Wheatley 1983) suggest it had a tribute-based economy, that it produced a surplus which was used to support foreign traders along its coasts and ostensibly to launch expansionistic missions to the west and south.

A substantial amount of archaeological research in Vietnam's Mekong delta since 1975 has concentrated on the "Oc Eo Culture" (Ha 1996; Trinh 1996 and Vo 2003 provide Western language summaries). Between 80 and 150 "Oc Eo culture" sites have been identified along the southern delta waterways, and many have been dated using chronometric or relative dating techniques. Many contain vestiges of brick monuments, some also have evidence of residential activity, and a small handful of sites have an occupational span that exceeded 500 years. The first millennium AD occupation of Cambodia's Mekong delta, in contrast, remains poorly documented. Before the launch of the LOMAP 2003-2005 survey, no systematic archaeological research had been undertaken in the area since Captain E.E. Lunet de Lajonquière's survey (Lunet de Lajonquière 1901, 1902-1911).

Thus, answering basic culture historical questions is a persistent goal of LOMAP research. LOMAP members also use multiple methodologies to address three key research questions. First, what were the roots of early polities in the Mekong delta? Secondly, how might we characterize their sociopolitical structure? Finally, do we have evidence for organizational changes through time? Our work focuses on both the site and regional levels, and this article presents preliminary findings from work still in progress. These provisional findings underscore the critical role of archaeological data in understanding early political developments in southern Cambodia, and enable us to evaluate the "received wisdom" of documentary accounts. This work also establishes a reliable timeline for the region's settlement history, and investigates the nature and timing of the area's initial settlement and subsequent expansion. LOMAP findings in and around Angkor Borei form the beginning of this discussion.

\section{FINDINGS FROM LOMAP FIELD INVESTIGATIONS IN THE ANGKOR BOREI AREA}

The site of Angkor Borei, whose walls enclose an area of 300 hectares, remains a primary locus of LOMAP research. Project members have investigated the site's developmental history, its ceramic variability, and aspects of the public works found around and within it. Figure 2 identifies LOMAP sampling locations for archaeological excavations and sediment coring until 2000. The highest densities of archaeological deposits lie in two areas: (1) the northern sector of the site, and (2) in a c. 500 m eastwest swath just south of the east-west channel that bifurcates the site. These areas have also experienced heavy looting activities since 1995. Almost all remnants of Angkor Borei's standing architectural features have now been dismantled, and their construction materials have been recycled for either new buildings or for road fill. Most sub-surface areas containing burials have been mined for saleable artifacts (especially beads, gold, and earthenware vessels), and bead mining activities continue to the present (Warne 2006:41-42). 


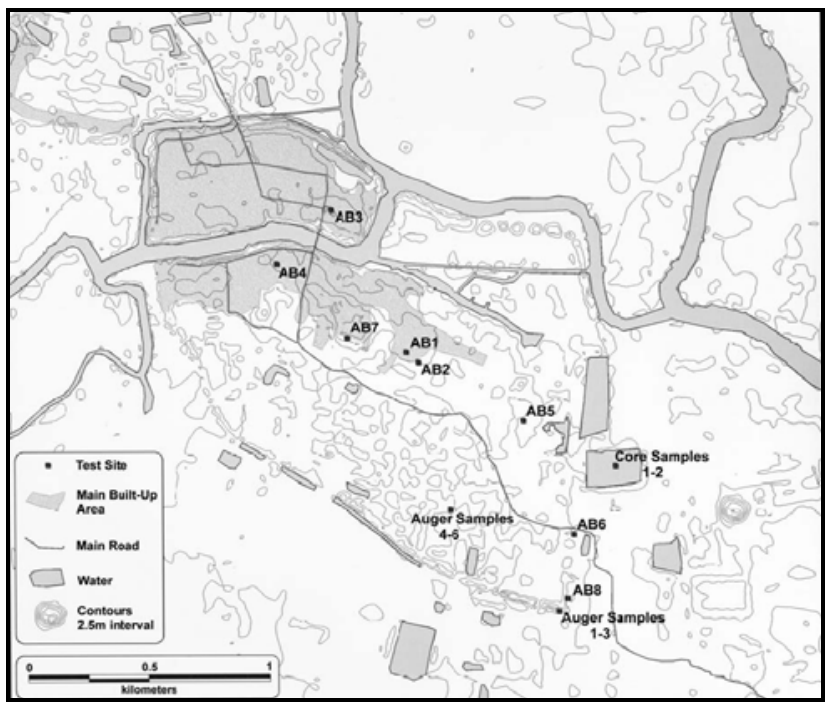

Figure 2. Contour map of Angkor Borei site showing the locations of archaeological excavations ("Test site”), and the eastern baray coring locality. The contour map was constructed by Mr. John Shearer, using 7127 elevation points derived photogrammetrically by Mrs. Anne Dunlop and Dr. Jane Drummond from Finnmap aerial photographs (1:25,000; December 1992, Roll 29, Strip 100, photos 7067, 7068, and 7069). Adapted with permission from Bishop et al. 2003b, Figure 3 in GEOARCHAEOLOGY@ 2003

Exploratory work in 1995 by the Cambodia Project sampled several areas as part of an archaeological field training program with graduates from the Royal University of Fine Arts (Stark et al. 1999:14-15). LOMAP excavations conducted in 1996, 1999 and 2000 concentrated on three different areas of the site, and produced parallel radiocarbon sequences. Work at Vat Komnou was the focus of LOMAP 1999 and 2000 excavations (Stark 2001). Salvage excavations at this locale produced a radiocarbon sequence that brackets the site's establishment no later than the $4^{\text {th }}$ century BC, which parallels sequences produced during the 1996 field season. Particularly notable was the cemetery layer, dating from c. 200 BC - AD 200, which constitutes a small portion of a much larger pre-Angkorian cemetery at Vat Komnou. Our work recovered the largest archaeological skeletal collection yet analyzed from Cambodia, and some findings from this work are summarized by Pietrusewsky et al. (2006).

An extremely well-dated ceramic collection was associated with the cemetery layer, and adds to our knowledge of the Angkor Borei ceramic tradition (Bong 2003; Stark 2003b). Table 1 presents the phase dating of ceramic groups from Angkor Borei, and Figure 3 illustrates diagnostic vessel forms. Phase 2a is found in all excavated sequences, and is visible throughout much of Angkor Borei in road cuts and gardening trenches. Phase 2b has only thus far been identified in the Vat Komnou cemetery layer; interviews with villagers, however, suggest that substantial areas across Angkor Borei contained subsurface mortuary remains and may thus contain this ceramic assemblage as well.
This ceramic sequence provides a useful tool for dating sites that we have documented through the 20032005 survey. While ceramic forms in this sequence have parallels found elsewhere in the Mekong delta (and particularly in Vietnam), we find it intriguing that the ceramic traditions bear little resemblance to contemporary traditions found in northwest Cambodia and northeast Thailand. These differences support the contention that the Mekong delta polities were focused southwards toward the China Sea network until some point after the $4^{\text {th }}$ century AD, but systematic survey is needed over a large geographic region to test this model adequately.

\section{LOMAP 2003-2005 SURVEY: METHODOLOGY AND PRELIMINARY FINDINGS}

The Takeo River catchment, which encompasses an area c. $35 \mathrm{~km}$ east-west by $35 \mathrm{~km}$ north-south, was designated as the LOMAP 2003-2005 survey area for three reasons. The first is that Bernard Philippe Groslier (1973:342-343) suggested that "Funan" and pre-Angkorian sites were clustered along minor tributaries in the Transbassac rather than along the Mekong and Bassac rivers themselves. Angkor Borei forms the easternmost large settlement in this area; further east lies the Plain of Reeds, which today is swampy and only lightly inhabited. To the southwest of Angkor Borei lies a sizable, low-lying area that was suitable for flood recession agriculture (Fox and Ledgerwood 1999) because of its annual inundation. Flood recession agriculture may have played an important role in the earliest occupation of this region (van Lière 1980; Ng 1979), because ancient populations could reap high rice yields with relatively low labor inputs. Flanking the eastern edge of this basin is the Takeo River. Although areas west of Angkor Borei fall into this flooded basin, areas east of the basin are sufficiently elevated to remain habitable during periods of peak flooding. The LOMAP survey region includes locations within a $30 \mathrm{~km}$ radius of Angkor Borei to its west and south along the Takeo River (Figures 4-6 bound this area).

A second parameter that bounds our survey region consists of a series of ancient canals, first documented by Pierre Paris (1931, 1941) and Louis Malleret (1959), and more recently by LOMAP crew members (e.g., Bishop et al. 2003a; Sanderson et al. 2003). These canals connect Angkor Borei to a series of sites that flank the Takeo River, and likely formed important transportation and communication networks to link settlements within a regional system. Our earliest canal samples date to c. 2000 BP. These dates identify the Takeo River drainage as a salient region and provide provisional support for Paris' claim that a canal linked Angkor Borei with Oc Eo and other Vietnamese sites (see also Bourdonneau 2003).

Investigating the origins, structure, and change through time in the Takeo River regional settlement system requires systematic archaeological survey to document the region's range of settlements from the midfirst millennium BC onwards. Accordingly, we sought to record the range of sites in the system and to obtain 
Table 1. Ceramic chronology from Angkor Borei.

\begin{tabular}{|c|c|c|c|c|c|}
\hline $\begin{array}{l}\text { Angkor } \\
\text { Borei } \\
\text { Phase } \\
\end{array}$ & Date range & $\begin{array}{l}\text { Dominant } \\
\text { ceramics }\end{array}$ & $\begin{array}{c}\text { Diagnostic ceramics } \\
\text { (and common } \\
\text { shapes) }\end{array}$ & $\begin{array}{l}\text { AB recovery } \\
\text { contexts }\end{array}$ & Reference \\
\hline 1 & $\begin{array}{c}\text { c. } 400 \mathrm{BC}-100 \\
\mathrm{BC}\end{array}$ & $\begin{array}{c}\text { Cord-marked } \\
\text { wares, incised } \\
\text { burnished wares }\end{array}$ & $\begin{array}{c}\text { Incised burnished } \\
\text { ware pedestalled } \\
\text { vases }^{1}\end{array}$ & $\mathrm{AB} 3, \mathrm{AB} 4$ & $\begin{array}{l}\text { Bong 2003; Stark } \\
\text { 2000, 2003b; Stark } \\
\text { et al. } 1999\end{array}$ \\
\hline $2 a$ & $\begin{array}{c}\text { c. } 100 \text { BC - c. A.D. } \\
200 / 300\end{array}$ & Fine orangewares & $\begin{array}{c}\text { Fine orangeware } \\
\text { cylinders }\end{array}$ & $\begin{array}{l}\text { AB3, AB4, } \\
\text { AB7 }\end{array}$ & $\begin{array}{l}\text { Bong 2003; Stark } \\
\text { 2000, 2003b; Stark } \\
\text { et al. } 1999\end{array}$ \\
\hline $2 b$ & $\begin{array}{c}\text { c. } 200 \mathrm{BC}-\mathrm{AD} \\
200\end{array}$ & Fine orangewares & $\begin{array}{c}\text { Fine orangeware } \\
\text { pedestalled bowls } \\
\text { and globular ring- } \\
\text { based jars }\end{array}$ & $\begin{array}{l}\text { AB } 7 \text { (Vat } \\
\text { Komnou } \\
\text { cemetery) }\end{array}$ & Stark 2001 \\
\hline 3 & $\begin{array}{c}\text { c. AD } 200 / 300- \\
? 600 ?^{2}\end{array}$ & Fine buffwares & $\begin{array}{l}\text { Buffware kendi jars } \\
\text { and other forms }\end{array}$ & $\mathrm{AB} 3, \mathrm{AB} 4$ & $\begin{array}{l}\text { Bong 2003; Stark } \\
\text { 2000, 2003b; Stark } \\
\text { et al. } 1999\end{array}$ \\
\hline
\end{tabular}

${ }^{1}$ Leng Rattanak (personal communication, April 2006) reported similar ceramics from Phnom Ambeng (Kompong Cham province).

${ }^{2}$ The terminus date of Phase 3 is inferred because of widespread destruction of the post-AD 300 materials across the site.

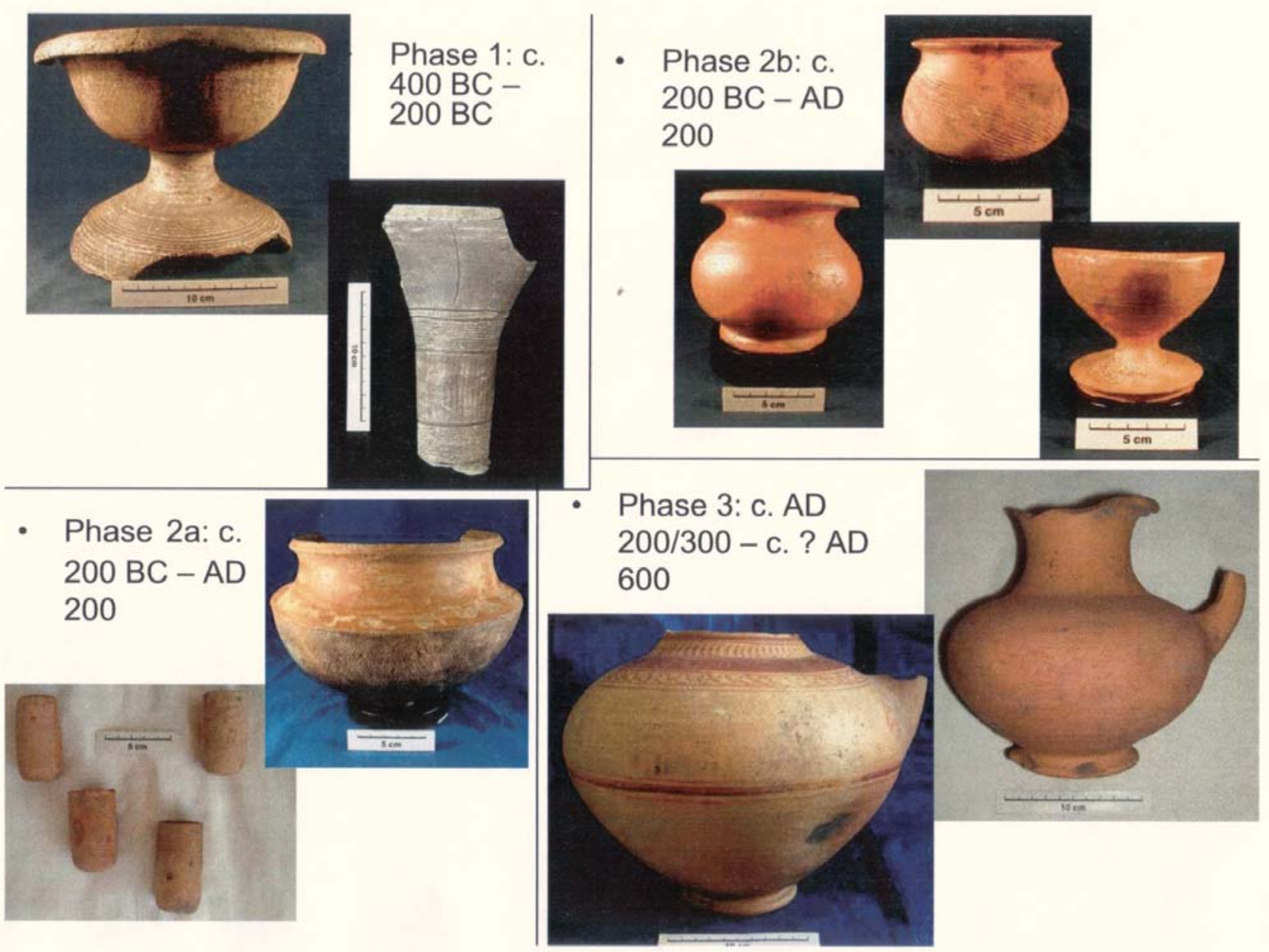

Figure 3. Vessel forms associated with each phase in the Angkor Borei ceramic chronology. Note that Phase 2a includes small cylindrical vessels. The Phase 3, left hand vessel, has red painted bands of decoration. 
estimates of their occupational spans in order to reconstruct interregional networks into the mid-first millennium AD. Students and graduates of the Archaeology Faculty at the Royal University of Fine Arts have joined archaeologists, geographers, and dating specialists in the field as part of this project. Because most of our studies are still underway, we only sketch the outlines of our research here.

LOMAP members have spent three consecutive field seasons engaged primarily in archeological survey: reconnaissance, mapping, and recording surface features. To maximize spatial coverage within the project area, the LOMAP survey relied on selective, rather than fullcoverage, survey techniques that drew from data sources described previously in this paper (e.g., art historical, epigraphic, aerial photographic). We counteracted this skew toward identifying sites with surface architectural manifestations (particularly moated-sites) by interviewing villagers about site locations that were not necessarily visible on our aerial photographs. Crew members also inspected likely areas of habitation, which are found along the edge of the floodplain (as identified on aerial photographs taken during the peak flooding period in December 1992). Accordingly, first millennium AD residential sites in the region may be underrepresented in the survey area because of leveling activities in connection with farming (see Wilkinson 2003:37-38 for parallel in the Near East), as are earlier "prehistoric" sites that are now overlain with alluvial deposits.

\section{Methods of Site Identification}

French archaeologists used aerial photographs to document Cambodian sites beginning as early as 1912 (Groslier 1952:55), and began a long tradition of using remote sensing imagery to document archeological sites in the region. Data from the 2003-2005 field seasons are now being entered into an integrated GIS database that includes a collection of remote sensing imagery as well as topographic maps. Satellite imagery will be used to detect relict channels, canal fragments, maximal flooding extent, and possibly pre-Angkorian field systems. Two series of aerial photographs provide quality information for identifying potential archaeological features (i.e., mounds and ponds): (1) 1990s FinnMap photos (which were digitized and orthorectified before the 2003 season, and analyzed to identify major areas that required LOMAP field investigations); and (2) 1950s aerial photographs taken by the French and described by Groslier (1952:6061).

The French military aerial photographs of the Mekong delta during the early 1950s offer a supplementary data source that is now being incorporated into the LOMAP GIS database. It is likely that they will contain more archaeological evidence than the 1990s FinnMap photos. During the late 1970s, the Khmer Rouge regime encouraged canal construction and the expansion of rice field areas in the region, which substantially modified the landscape (Helmer 1997). Interviews with local farmers indicate that during the subsequent Vietnamese regime (1979-1989), resettled populations cleared previous scrubland to expand farm plots, looted archaeological mounds and, where possible, flattened mounds to increase their field areas.

Prior to each field season, potential pre-Angkorian sites were identified through combining remote sensing data (primarily the 1992 FinnMap aerial photographs) and information from French colonial archaeological reports into a Geographic Information Systems database. Reliance on this database facilitated systematic (rather than full-coverage) survey techniques that maximized the number of sites recorded. Archaeological fieldwork involved ground-truthing these potential sites, interviewing villagers to obtain site histories and to ascertain locations of other potential sites, and pedestrian reconnaissance. A variety of transport vehicles were used to reach archaeological sites, including speedboats, trucks, motorbikes, and pony carts. Field visits first involved consultation with local and district officials to obtain permission to work and to identify the range of already-known sites in the community.

\section{Localities Documented from 2003-2005}

Approximately 272 localities were documented in the 2003, 2004 and 2005 field seasons (Table 2). Each field season's survey crews utilized the same methodologies outlined previously, and attention focused on different parts of the survey region each season. Survey work was undertaken along with paleoenvironmental research and investigations of potentially ancient canal segments as part of the Paris Canal research headed by Dr. Paul Bishop (University of Glasgow).

Table 2. Preliminary mound counts from LOMAP 20032005 Survey.

\begin{tabular}{|l|l|}
\hline Field Season & \# Mounds \\
\hline 2003 & 114 \\
\hline 2004 & 80 \\
\hline 2005 & 78 \\
\hline TOTAL & 272 \\
\hline
\end{tabular}

Our 2003 field season focused on sites adjacent to the river and on a series of sites immediately northwest of Angkor Borei. Survey concentrated on sites that followed the Takeo River downstream, and these sites are identified in Figure 4. Archaeological sites were recorded along the eastern border of the Takeo River; a sample of the second set of sites lying further east of the floodplain was also documented. Two areas of dense pre-Angkorian settlement were located near Phum Prey Phdao Knong and Phum Kompong Youl, both of which are linked to Angkor Borei by "Paris" canals (see Fig. 4). The last two weeks of survey focused on selected areas to the north of Angkor Borei.

Most documented sites consist of mounds and associated water features (moats and/or trapeang [small 


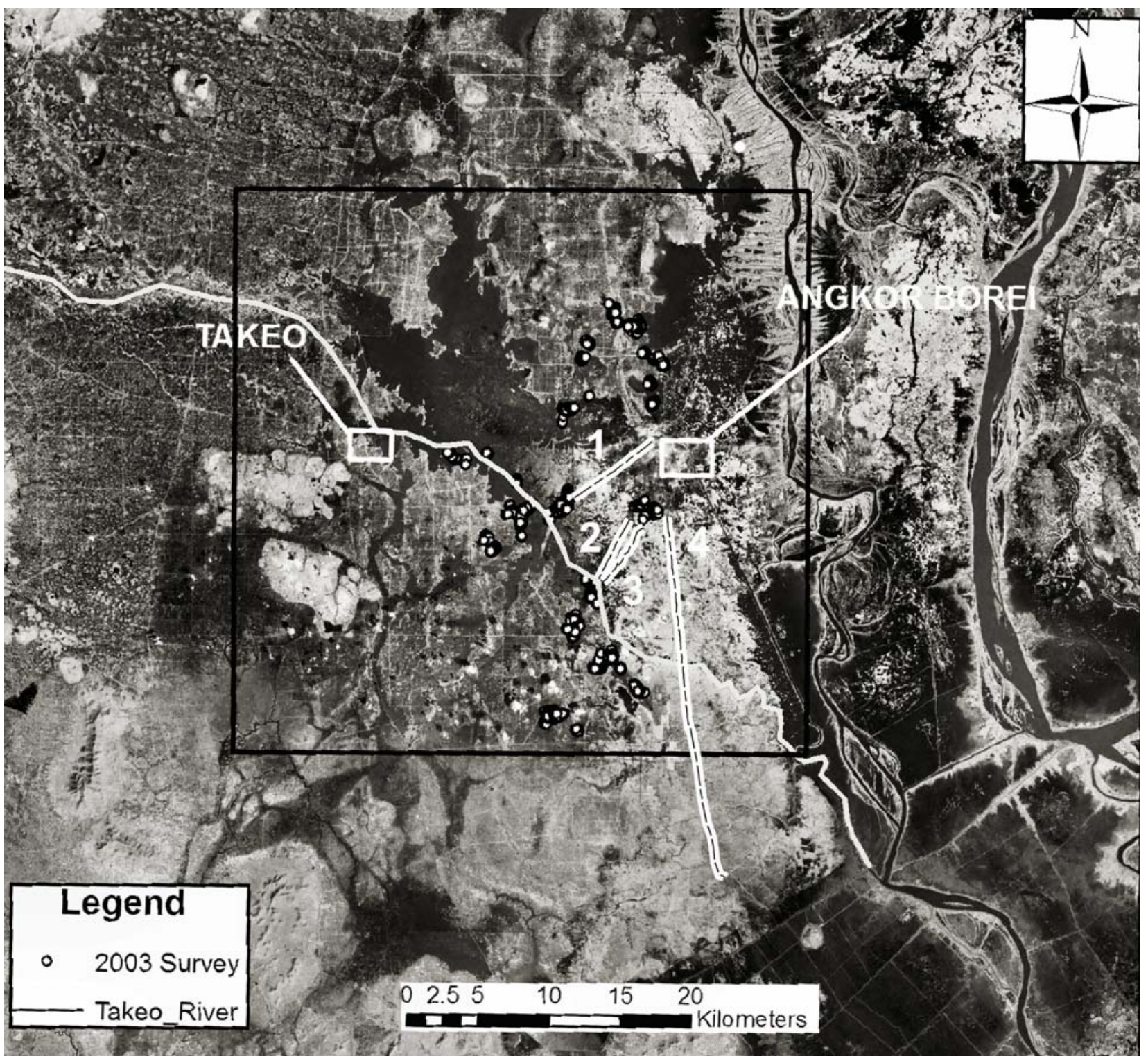

Figure 4. Archaeological localities identified during the LOMAP 2003 field survey. Note locations of inferred Paris canals (1-4) superimposed on figure.

ponds]). The LOMAP 2003 survey crew documented 114 mounds in or near 20 separate villages (or phum) during the field season, including both mounds containing brick and brickless mounds. Mounds tended to occur in clusters, often in conjunction with ponds. A large number of these mound clusters was recorded in, or directly adjacent to, contemporary villages, and many of these villages have been built atop dense ceramic artifact scatters. Occasionally, collapsed brick structures were also found in such villages. All brick structures identified through survey have collapsed, and most bear evidence of looting.

The LOMAP 2004 field season expanded geographic coverage to the west along the fringes of the Takeo River floodplain. Figure 5 identifies all LOMAP 2004 surveyed localities, which includes a total of 80 new mounds in, or located directly adjacent to, 19 separate phum during the field season. Of these mounds, 66 lay in villages outside the boundaries of Angkor Borei; the remaining 14 mounds were documented in three phum within the walled area that is Angkor Borei. Permissions were also obtained from local landowners to sample seven collapsed brick structures for luminescence dating purposes.

Work during the LOMAP 2005 field season focused to the west of and away from the Takeo River, and also began exploring the region between Phnom Chisor (to the north) and Angkor Borei (to the south). Figure 6 presents all 78 localities surveyed by LOMAP 2005 in, or directly adjacent to, 10 separate phum. All these communities had large numbers of moated mounds in various configurations that we mapped and photographed. Significant time was also devoted to revisiting some localities found in 2003 and 2004 to ensure full coverage of the region, and to link the 2005 localities into larger 


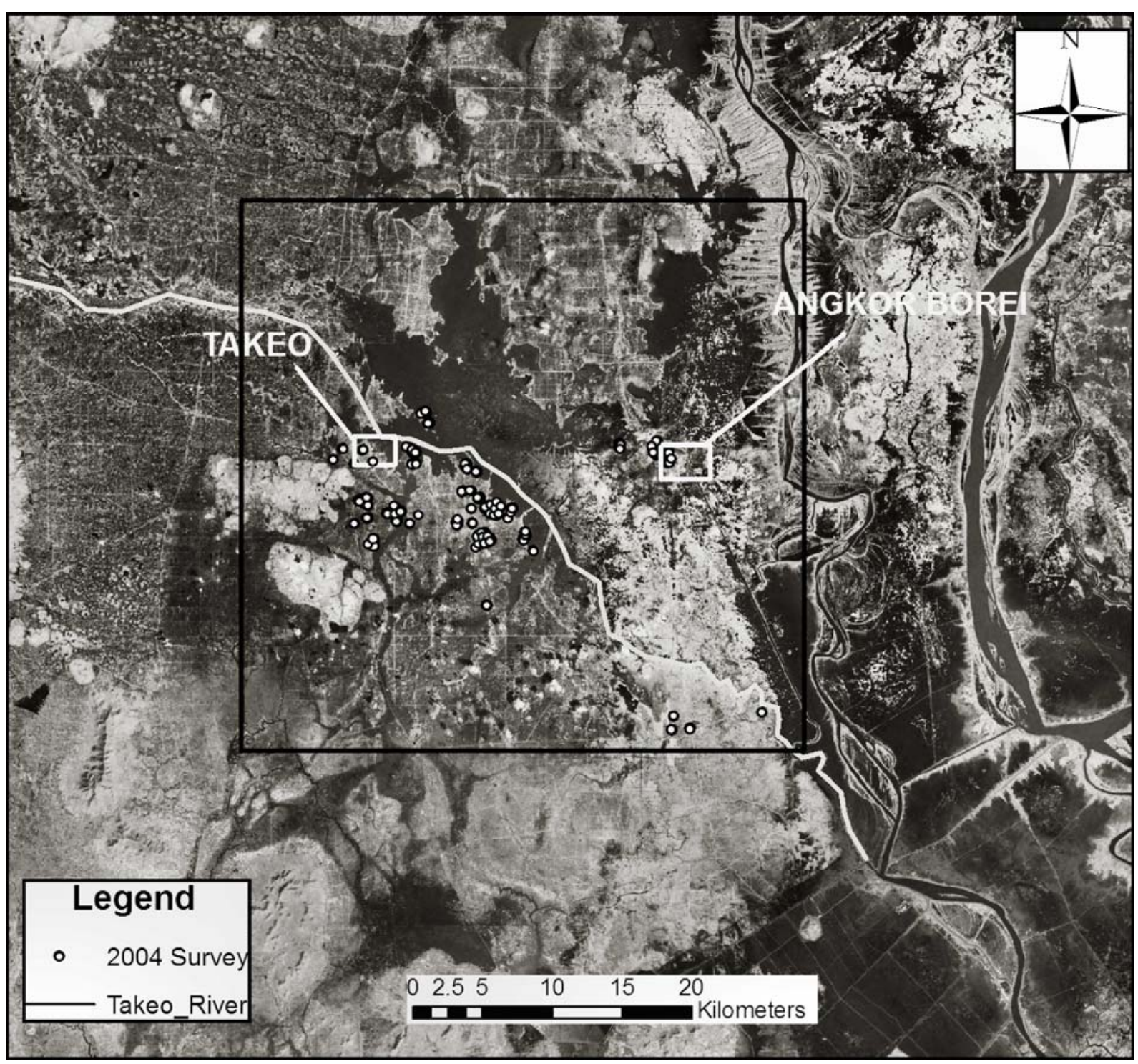

Figure 5. Archaeological localities identified during the LOMAP 2004 field survey.

clusters, some of whose mounds were mapped in previous field seasons.

\section{LOMAP Unit Definition and the Notion of "Site"}

Combining data from field investigations and aerial photographic analysis generates a complicated data set that underscores key debates concerning the term "site" as it is used in archaeological survey research (see for example Anschuetz et al. 2001:171-172). Surveying Asian areas of wet-field rice agriculture further complicates the debate (Barnes 1986). Despite these caveats, the term "site" was provisionally applied to a series of archaeological localities during the LOMAP 2003-2005 survey. As has been noted in previous surveys in the region (e.g., Mudar 1995), the most effective criterion was a marked increase in the density of artifacts encountered that signaled the presence of a residential locality. Given the Mekong delta's active alluvial depositional nature, the majority of "sites" encountered during survey were characterized primarily by their architectural features rather than by high artifact densities. Most architectural sites had either a very thin artifact scatter (ceramics and or brick) or no artifacts whatsoever, and were instead marked by the presence of associated moats and ponds. GPS units were used to demarcate the boundaries of these feature complexes, and visible mounds were mapped using standard transit technology.

Three primary archaeological remains were identified during the LOMAP 2003-2005 field survey seasons: moated mounds, artifact concentrations, and water control features. Some localities contained all three kinds of remains; while other localities consisted of a single moated mound. The vast majority of sites we documented had one or more moated mounds, and these were commonly located away from contemporary Khmer villages in prime agricultural areas. In a few cases, the moated mounds were found directly adjacent to, or 


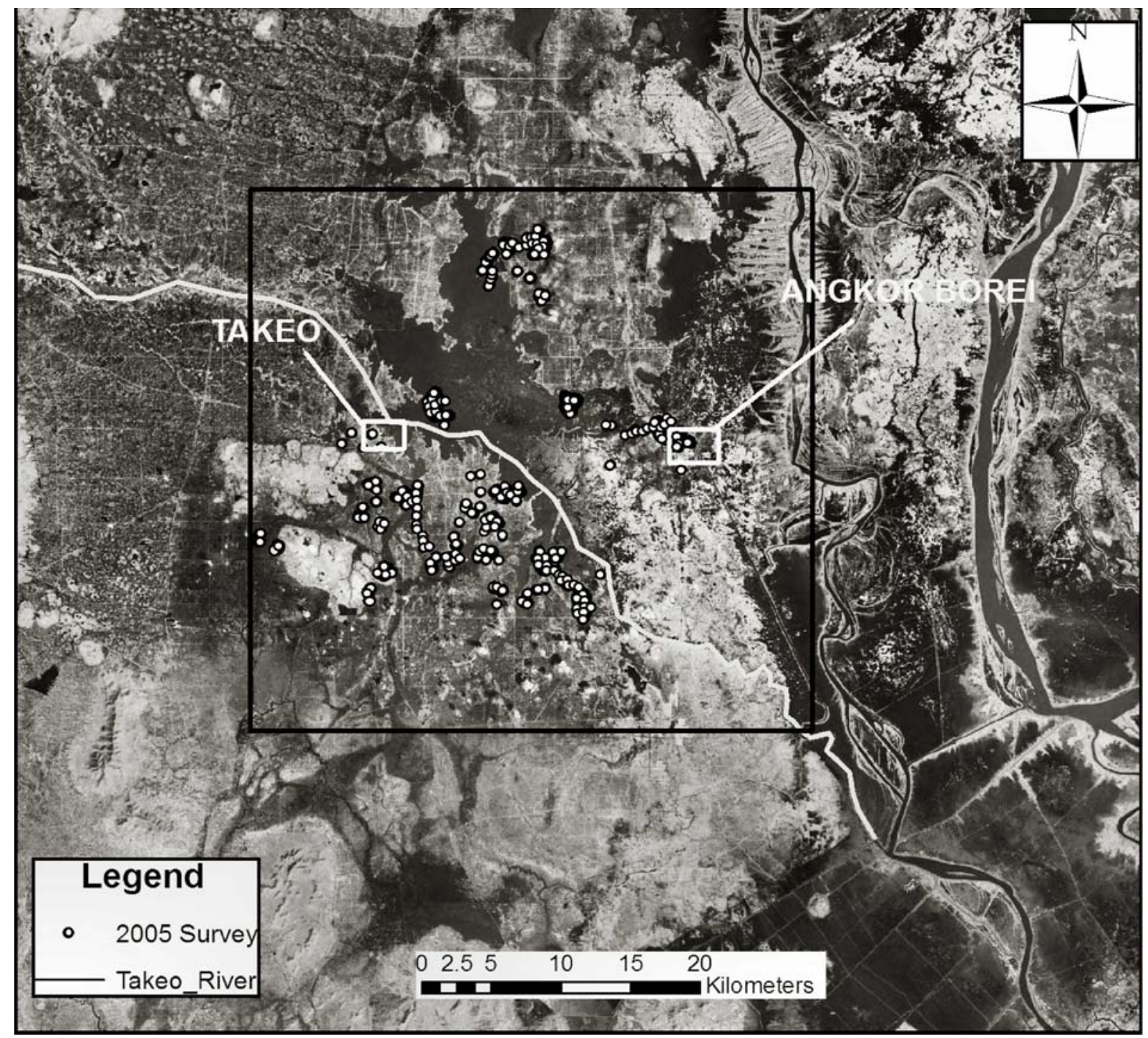

Figure 6. Archaeological localities identified during the LOMAP 2005 field survey.

within, villages. Some villages (but not the mounds themselves) also contained subsurface ceramic deposits that suggest a pre-Angkorian residential function.

A small number of localities contained portions of intact brick masonry, a larger number contained brick fragments, and many mounds contained no brick whatsoever. To what extent this pattern reflects relatively recent dismantling activities (for recycling bricks, for clearing fields, and so on) remains unclear. In his early $20^{\text {th }}$ century survey of the region, Lunet de la Jonquière reported that most brick shrines had already been dismantled. Many mounds that the LOMAP 2003-2005 field season visited contained some brick fragments; a smaller number contained portions of brick architecture (Stark et al., this volume). Most brick localities that we documented were quite fragmentary, and finding intact masonry was difficult.

Usage of the term "site" in the LOMAP 2003-2005 archaeological survey is indeed complex: some moated mounds along the Takeo River appeared in complexes of several mounds that are found in close vicinity to one or more contemporary communities. In Figure 7, for example, we see mounds associated with the contemporary communities of Preak Moreah and Kampram. At least eight mounds were still visible in the vicinity of Kampram (to the west), but the only residential archaeological site in the region lay across the Takeo River under the community of Preak Moreah. As another example, one complex of more than ten mounds in the southern part of the survey region covered an agricultural area that lacked any archaeological evidence of residential activity. These patterns, still under investigation, suggest that first-millennium AD moated mounds in the northern Mekong delta did not serve a predominantly residential function. They thus differ in function and form from documented circular earthwork sites in the "Terre Rouges" area of Kompong Cham and Vietnam (e.g., Albrecht et al. 2001; Dega 2002; Kojo and Pheng 1998; Moore 1988, 1990, 1992, 1998).

Archaeological mounds in the survey region formed clusters, and these clusters form units that may be considered "sites." These clusters also have close spatial 


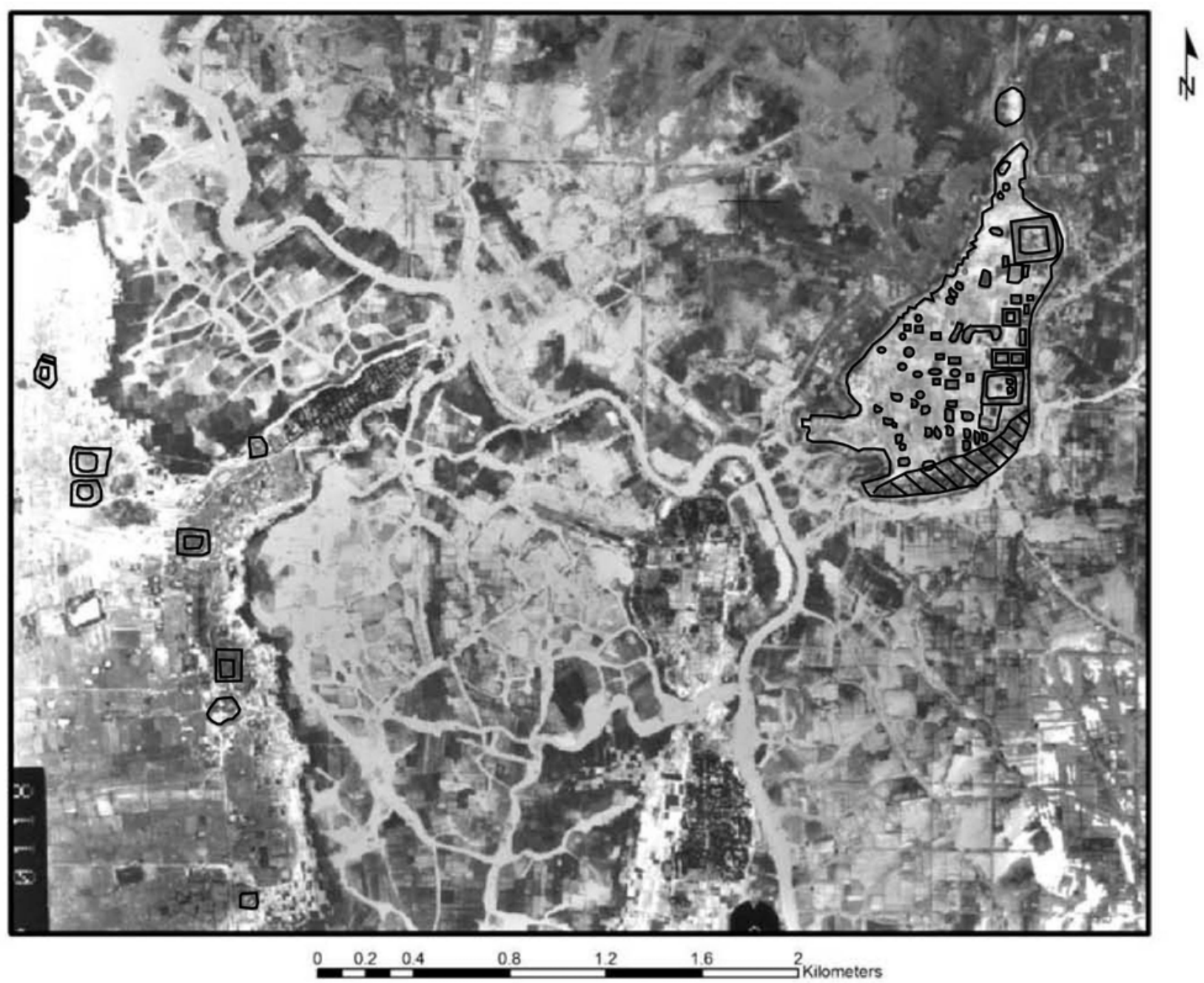

Figure 7. Example of archaeological 'site’ cluster: Preak Moreah and Kampram (LOMAP 2003 GPS data transposed on FinnMap).

relationships to each other. Work is now underway to date localities and clusters through either chronometric or relative dating. The former method relies on luminescence dating of associated brick monuments, while the latter relies on the ceramic chronology developed through excavations at Angkor Borei.

A total of 8 brick monuments within Angkor Borei and in the LOMAP survey area have now been sampled for thermo- and optically-stimulated luminescence dating techniques (Stark et al., this vcolume). Seven of these have yielded reliable dates, and ongoing work is assigning relative dates to all survey localities which contained surface ceramic scatters. The next step is to characterize variability in these mounds and clusters to understand their configurations and the relationship of moated mounds to residential areas. We will also characterize the potential land-use strategies around each residential site to begin reconstructing the ancient farming systems that supported the growing delta populations of the first millennium AD.

\section{DISCUSSION AND CONCLUSIONS}

Construction of remote sensing data layers for the LOMAP 2003-2005 survey database is ongoing, and analysis of locality type and associated artifacts is still in its early stages. A growing body of archaeological evidence, however, supports the French claim that Angkor Borei was a large regional center during the period we associate with Funan. It also suggests that the region's importance continued unabated throughout the pre-Angkorian period, a point that Jacob (1979) and Vickery (1998) raised previously. Equally interesting is the observation that most chronometrically-dated brick monuments in Angkor Borei and in the LOMAP survey region postdate $\mathrm{AD} 500$, and that at least three bear Angkorian-period dates and suggest the continued importance of the delta.

At a broader level, answering the kinds of cultural historical questions that concern the rise of centralized power during the Angkorian period require archaeologists to work in multiple settings throughout the Mekong basin. 
What westerners call "historical archaeology" in Cambodia (that is, research done on periods with documentary evidence) has traditionally privileged documentary sources over systematic archaeological research. In fact most of the "conventional wisdom" regarding the origins, rise, and 'collapse' of the Angkorian world is 'known' through historical, rather than archaeological evidence (Stark 2006).

Pre-Angkorian archaeology has never been in a better position than today: a growing number of trained Khmer professionals work with foreigners on long-term international collaborative research projects in several of the country's provinces. Systematic archaeological research is still needed to document developmental sequences in central Cambodia (from Kratie to Kompong Thom) and around the Tonle Sap. Both archaeological survey and technical research are needed to date brick monuments in these regions, test the stylistic chronologies that have formed the basis for our temporal assignments, and identify the scale of nature of residential systems. It is within this broader context of pre-Angkorian archaeology that LOMAP can make its greatest contribution, and this enriched understanding of the pre-Angkorian period will provide insights - and may well require reinterpretation of the rise and demise of the Khmer empire.

\section{ACKNOWLEDGMENTS}

I extend my sincerest thanks to Cambodia's Ministry of Culture and Fine Arts and the Royal University of Fine Arts for permission and support of the Lower Mekong Archaeological Project. Thanks are also due to several funding agencies that supported LOMAP Phase III research: National Science Foundation (USA), Center for Khmer Studies (USA, Cambodia), and the National Geographic Society (USA). The LOMAP 2003-2005 survey fieldwork could not have been completed without the assistance of LOMAP crew members Nigel Chang, Ya Da, Heng Piphal, Mao Cheng Leng, Seng Kompheak, Heng Sophaddy, Stephen Acabado, Wannasarn Noonsuk, Khut Sokhan, Va Inariddh, Chea Socheat, Seng Chantha, Huot Samnang, Ben Sokvat, Mak Kun, Long Monika, Phon Chea Kosal, Sorn Son Sopheath, Alison Carter, Wesley Clarke, Judith van den Berg, Sirik Kada, Teressa Davis, Ben Marwick, and Benjamin Rabitor. Researchers Paul Bishop, David Sanderson, and Dan Penny are an integral part of LOMAP and I thank them for their regular support. I thank Leng Rattanak for unpublished comparative ceramic information, Peter Bellwood for editorial suggestions, and the Angkor Borei district office and community for their hospitality during our field research. Gratitude is also extended to Takeo communities with which we have worked through the LOMAP 2003-2005 survey. Peter Bellwood provided useful editorial comments, and graphics assistance was provided by Stephen Acabado, Amy Commendador, Alex Morrison, and Jo Lynn Gunness.

\section{REFERENCES CITED}

Albrecht, G., M.N. Haidle, S. Mao, S. Chor, H. Sophady, H. Than, M. Someaphyvath, S. Kada,T Chanthourn, V. Laychour. 2001. Circular Earthwork Krek 52/62: Recent research on the prehistory of Cambodia. Asian Perspectives 39(1-2):2-46.

Anschuetz, K. F. R. H. Wilshusen and C. L. Scheick. 2001. An archaeology of landscapes: Perspectives and directions. Journal of Archaeological Research 9:157-211.

Barnes, G. L. 1986. Paddy field archaeology in Nara, Japan. Journal of Field Archaeology 13(4): 371-379.

Bishop, P., D. C. W. Sanderson, and M. T. Stark. 2003a. OSL and radiocarbon dating of a pre-Angkorian canal in the Mekong Delta, southern Cambodia. Journal of Archaeological Science 31(3):319-336.

Bishop, P., D. Penny, M. T. Stark and M. Scott. 2003b. A 3.5ka record of paleoenvironments and human occupation at Angkor Borei, Mekong Delta, southern Cambodia. Geoarchaeology 18(3):1-35.

Bong, S. 2003. The Ceramic Chronology of Angkor Borei, Takeo Province, Southern Cambodia. PhD dissertation, University of Hawaii.

Bourdonneau, E. 2003. The ancient canal system of the Mekong Delta: A preliminary report. In A. Karlström and A. Källén, (eds.), Fishbones and Glittering Emblems: Southeast Asian Archaeology 2002, pp. 257-270. Stockholm: Museum of the Far Eastern Antiquities.

Coedès, G. 1968. The Indianized States of Southeast Asia. University of Hawaii Press, Honolulu.

Dega, M. F. 2002. Prehistoric Circular Earthworks of Cambodia. BAR International Series 1041. Oxford: Archaeopress.

Fox, J. and J. Ledgerwood. 1999. Dry-season flood-recession rice in the Mekong delta: two thousand years of sustainable agriculture? Asian Perspectives 38(1):37-50.

Griffin, P. B., Ledgerwood, J., and Chuch Phoeurn. 1999. The Royal University of Fine Arts, East-West Center, and University of Hawaii Program in the archaeology and anthropology of the Kingdom of Cambodia, 1994-1998. Asian Perspectives 38(1):1-6.

Griffin, P. B., Ledgerwood, J. and Stark, M. T., 1996. Education, and cultural resource management at Angkor Borei, Cambodia. CRM: Cultural Resources Management 19(3):37-41.

Groslier, B.P. 1952. L'avion et l'archéologie Indochinoise. Forces Aériennes Françaises 67:51-63.67:

Groslier, B. P. 1973. Pour une géographie historique du Cambodge. Les Cahiers d'Outre-Mer 104(26):337-379.

Ha Van Tan. 1986. Oc Eo: Endogenous and exogenous elements. Vietnam Social Sciences 1-2(7-8): 91-101.

Hall, K. 1982. The "Indianization” of Funan: An economic history of Southeast Asia's first state. Journal of Southeast Asian Studies 13:81-106.

Hall, K. 1985. Maritime Trade and State Development in Early Southeast Asia. Honolulu: University of Hawai'i Press.

Helmers, K. 1997. Rice in the Cambodian economy: past and present. In Rice Production in Cambodia, edited by H. J. Nesbitt, pp. 1-14. Manila, Philippines: International Rice Research Institute. 
Ishizawa, Y. 1996. Chinese chronicles of 1st-5th century A.D. Funan, southern Cambodia. In R. Scott and J. Guy (eds.), South East Asia \& China: Art, Interaction \& Commerce, Colloquies on Art \& Archaeology in Asia No. 17, pp. 1731. London: University of London Percival David Foundation of Chinese Art.

Jacob, J. M. 1979. Pre-Angkor Cambodia: Evidence from the inscriptions concerning the common people and their environment. In R. B. Smith and W. Watson (eds.), Early South East Asia, pp. 406-424. New York: Oxford University Press.

Jacques, C. 1979. 'Funan,' 'Zhenla': The reality concealed by these Chinese views of Indochina. In R. B. Smith and W. Watson (eds.), Early South East Asia: Essays in Archaeology, History, and Historical Geography, pp. 371-379.New York: Oxford University Press.

Jacques, C. 1995. China and ancient Khmer history. In South East Asia \& China: Art, Interaction \& Commerce, Colloquies on Art \& Archaeology in Asia No. 17, edited by R. Scott and J. Guy, pp. 32-40. London: University of London Percival David Foundation of Chinese Art.

Kojo, Y. and Pheng S. 1998. A preliminary investigation of a circular earthwork at Krek, southeastern Cambodia. Anthropological Science 106(3):229-244.

Lunet de Lajonquière, E. E. 1901. Atlas archéologique de l'Indo-Chine: Monuments du Champa et du Cambodge. Paris: Publications de l'École Française d'Extrême Orient.

Lunet de Lajonquière, E. E. 1902-1911. Inventaire descriptif des monuments du Cambodge. 3 vols. Paris: Publications de l’École Française d'Extrême Orient vol. IV, VIII-IX.

Malleret, L. 1959. L'Archéologie du Delta du Mékong, Part 1. L'Exploration Archéologique et Les Fouilles d'Oc-Èo. Paris: École Française d'Extrême-Orient.

Malleret, L. 1960. L'Archéologie du Delta du Mékong, Part 2. La Civilisation Matérielle d’Oc-Ėo. 2 vols. Paris: École Française d'Extrême-Orient.

Malleret, L. 1962. L'Archéologie du Delta du Mékong, Part 3. La Culture du Fou-Nan, 2 vols. Paris: École Française d'Extrême-Orient.

Moore, E. H. 1988. Notes on two types of moated settlement in Northeast Thailand. Journal of the Siam Society 76:275287.

Moore, E. H. 1990. Moated settlement in the Mun Basin, Northeast Thailand. In I. C. Glover and E. Glover (eds.), Southeast Asian Archaeology 1986: Proceedings of the First Conference of the Association of Southeast Asian Archaeologists in Western Europe, pp. 210-212. BAR International Series 56. Oxford, England: Archaeopress.

Moore, E. H. 1992. Water enclosed sites: Links between Ban Takhong, Northeast Thailand and Cambodia. In J. Rigg (ed.), The Gift of Water: Water Management, Cosmology and the State in Southeast Asia, pp. 26-46. London: School of Oriental and African Studies.

Moore, E. H. 1998. The prehistoric habitation of Angkor. In P.Y. Manguin (ed.), Southeast Asian Archaeology 1994. Proceedings of the 5th International Conference of the European Association of Southeast Asian Archaeologists, Paris, 24th-28th October 1994, Vol. I, pp. 27-36. University of Hull, England: Centre for South-East Asian Studies.

Mudar, K.M. 1995. Evidence for prehistoric dryland farming in mainland Southeast Asia: Results of regional survey in
Lopburi Province, Thailand. Asian Perspectives 34(2):157-194.

Ng, R. C. Y. 1979. The geographical habitat of historical settlements in mainland Southeast Asia. In R. B. Smith and W. Watson (eds.), Early South East Asia: Essays in Archaeology, History, and Historical Geography, pp. 262-272. New York: Oxford University Press.

Paris, P. 1931. Anciene canaux reconnus sur photographies aeriennes dans les provinces de Ta-Kev et de Chau-Doc. Bulletin de l'École Française d'Extrême Orient 31:221224.

Paris, P. 1941. Notes et mélanges: ancienes canaux reconnus sur photographies aeriennes et les provinces de Ta-Keo, Chau-Doc, Long Xuyen et Rach-Gia. Bulletin de l'École Française d'Extrême Orient 41:365-370.

Pietrusewsky, M., R. Ikehara, and M.T. Douglas. 2006. The Bioarchaeology of the Vat Komnou Cemetery, Angkor Borei, Cambodia. Paper presented at the $18^{\text {th }}$ Congress of the Indo-Pacific Prehistory Association Meeting, March 20 - 26, 2006, Manila, Philippines.

Sanderson, D.C.W., P. Bishop, M. T. Stark, J.Q. Spencer. 2003. Luminescence dating of anthropogenically reset canal sediments from Angkor Borei, Mekong Delta, Cambodia. Quaternary Science Reviews 22 (2003):1111-1121.

Stark, M. T. 1998. The transition to history in the Mekong Delta: A view from Cambodia. International Journal of Historical Archaeology 2(3):175-204.

Stark, M. T. 2001. Some preliminary results of the 1999-2000 archaeological field investigations at Angkor Borei, Takeo Province. Udaya: Journal of Khmer Studies 2:1936.

Stark, M. T. 2003a. Angkor Borei and the archaeology of Cambodia's Mekong Delta. In J. Khoo (ed.), Art \& Archaeology of Fu Nan: Pre-Khmer Kingdom of the Lower Mekong Valley, pp. 87-106. Bangkok: Orchid Books.

Stark, M. T. 2003b. The chronology, technology and contexts of earthenware ceramics in Cambodia. In J. Miksic (ed.), Earthenware in Southeast Asia, pp. 208-229. Singapore: Singapore University Press.

Stark, M.T. 2006. From Funan to Angkor: Collapse and regeneration in ancient Cambodia. In G. Schwartz and J. Nichols (eds.), After Collapse: The Regeneration of Complex Societies, pp. 144-167. Tucson: University of Arizona Press.

Stark, M. T. and Bong Sovath 2001. Recent research on the emergence of early historic states in Cambodia's Lower Mekong. Bulletin of the Indo-Pacific Prehistory Association 19: 85-98.

Stark, M.T., P. B. Griffin, Chuch Phoeurn, J. Ledgerwood, M. Dega, C. Mortland, Dowling, J. M. Bayman, Bong S., Tea V., Chhan C., and D. K. Latinis. 1999. Results of the 1995-1996 field investigations at Angkor Borei, Cambodia. Asian Perspectives 38: 1:7-36.

Trinh Thi Hòa. 1996. Réflexions sur les vestiges de la culture d’Óc Eo. Etudes Vietnamiennes N. S. 50 120):111-123.

van Liere, W. J. 1980. Traditional water management in the lower Mekong Basin. World Archaeology 11(2):265-280.

Vickery, M. 1998. Society, Economics, and Politics in PreAngkor Cambodia: The 7th-8th Centuries. Tokyo: The Centre for East Asian Cultural Studies for Unesco, The Toyo Bunko. 
Vo Si Khai. 2003. The Kingdom of Fu Nan and the culture of Oc Eo. In Art \& Archaeology of Fu Nan: Pre-Khmer Kingdom of the Lower Mekong Valley, ed by J. C. M. Khoo, pp. 35-86. Bangkok: Orchid Press.

Voeun, V. and von den Driesch, A. 2004. Fish remains from Angkor Borei archaeological site in the Mekong Delta, Cambodia. In V. Paz (ed.), Southeast Asian archaeology: Wilhelm G. Solheim II Festschrift, pp. 400-410. Quezon City: University of the Philippines Press.
Warne, L. 2006. Buddhism, Looting and Relics from an Idealized Past: Apotropaic Use of Khmer Antiquities and Consequent Implications for the Illicit Antiquities Market in Cambodia. Unpublished MA dissertation, Department of Archaeology, University of Cambridge.

Wheatley, P. 1983. Nagara and Commandery: Origins of the Southeast Asian Urban Traditions. Research Paper Nos. 207-208. Chicago: Department of Geography, University of Illinois.

Wilkinson, T. J. 2003. Archaeological Landscapes of the Near East. Tucson: University of Arizona Press. 